\title{
The Effect of Earnings Management, Managerial Ownership, and Firm Size on Environmental Disclosure with Environmental Performance as Moderating
}

\author{
Vida Chusnia Chaq ${ }^{* 1}$ and Agus Wahyudin ${ }^{2}$ \\ 1,2Accounting Department, Faculty of Economics, Universitas Negeri Semarang
}

\begin{abstract}
ARTICLE INFO
\section{Article History:}

Received May 09 ${ }^{\text {th }}, 2019$

Accepted March $3^{\text {th }}, 2020$

Available March 30 $0^{\text {th }}, 2020$

\section{Keywords:}

environmental disclosure; earning management; managerial ownership; firm size; environmental performance

ABSTRACT

The purpose of this study is to analyze and determine the effect of earnings management, managerial ownership, and firm size on environmental disclosure by environmental performance as moderation. Non-financial companies listed on the Indonesia Stock Exchange (IDX) during 2014-2017 as many as 385 companies were taken as the population in this study. The use of purposive sampling method produced 64 units of analysis from 16 companies. Moderate regression analysis through absolute number differences was applied as a data analysis technique using the IBM SPSS 24 Program. The results of this study indicate that earnings management, managerial ownership, and firm size do not have significant effect on environmental disclosure. In addition, environmental performance does not significantly moderate the effect of earnings management on environmental disclosure and does not significantly moderate the effect of firm size on environmental disclosure. Environmental performance can only significantly moderate the effect of managerial ownership on environmental disclosure. This study concludes that only managerial ownership driven by environmental performance will affect the extent of the company's environmental disclosure.
\end{abstract}

(C) 2020 Published by UNNES. This is an open access article under the CC BY license (http://creativecommons.org/licenses/by/4.0/)

\section{INTRODUCTION}

In Indonesia, company has the obligation to disclose social and environmental responsibility. Law of the Republic of Indonesia concerning "Limited Liability Companies" Number 40 of 20072007 states that if company operates business activities related to the use of natural resources, it is required to carry out social and environmental responsibility activities. Further policy is available at Government Regulation Number 47 of 2012 concerning Limited Corporate Social and Environmental Responsibility. IAI in PSAK Number 1 (2012) paragraph 9 also proposes the disclosure of responsibility for social and environmental issues. This makes environmental disclosure is mandatory. However, the framework and content of reporting on social and environmental responsibility has not been regulated and is still voluntary.

Regulations regarding social and environmental responsibility are expected to increase environmental disclosure, but environmental disclosure in Indonesia is still relatively low. Research by Diantimala \& Amril

\footnotetext{
*E-mail: vidachusnia01@gmail.com

_Address: L2 Building 2nd floor, Campus Sekaran, Gunungpati, Semarang, Indonesia, 50229
}

(2018) said that the environmental disclosure of companies participating in PROPER in Indonesia only held an average of 0.1415 in 2010-2014. Dewi \& Yasa (2017) stated that the average environmental disclosure is 0.2053 in 2012-2015 in non-financial companies in Indonesia. Meanwhile Ningsih (2017) found the average environmental disclosure of 0.34 .

Low level of environmental disclosure is accompanied by environmental damage events produced by corporate operations. As conducted by PT Bukit Asam Tbk (www.globalplanet.news,2018), PT Vale Indonesia Tbk (walhi.or.id, 2017) and PT Aneka Tambang tbk (Poskonawes.com,2017) which result in environmental pollution. Indonesian Forum for the Environment (Walhi, 2018) also mentions that throughout 2017, 302 environmental and agrarian cases occurred in 13 provinces in Indonesia and 118 of them were cases of environmental pollution.

Environmental disclosure is a medium for companies to explain environmental activities and corporate social responsibility to maintain company's reputation and presence in the market and also to maintain company's survival (Diantimala \& Amril, 2018). Several factors are predicted to affect corporate environmental disclosure, including earnings management, manage- 
rial ownership, and firm size. The results of research conducted by Machmuddah et al., (2017) and Ningsih (2017) show the effect of earnings management with environmental disclosure has a significant positive relationship. Meanwhile, Sunet al, (2010) and Julianto \& Sjarief (2016) obtained that earnings management does not have a significant effect on environmental disclosure.

Research of managerial ownership on environmental disclosure conducted by Oktafianti \& Rizki (2015) and Fashikhah et al., (2018) show managerial ownership and environmental disclosure have a significant positive effect. Khan et al., (2013) proved that managerial ownership and environmental disclosure have a significant negative effect. Meanwhile, Chang \& Zhang (2015), Donnelly \& Mulcahy (2008), and Ningsih (2017) stated there is no significance of the relationship between managerial ownership and corporate environmental disclosure.

Diantimala \& Amril (2018), Ashfaq \& Rui (2018), Ismail et al., (2018) produced finding that firm size has a significant positive effect on corporate environmental disclosure. Other studies conducted by Darus et al.(2014), Ariningtika \& Kiswara (2013) and Anggrarini \& Taufiq (2017) find that firm size does not affect environmental disclosure significantly.

Some studies show that there are still gaps in research results. The purpose of this study is to examine the effect of earnings management, managerial ownership, and firm size on environmental disclosure moderated by environmental performance in non-financial companies in 2014-2017. The originality in this study is the presence of environmental performance as a moderating variable. Ismail et al.(2018) defined environmental performance as an environmental certification that shows interest and willingness of a company to improve environmental quality. The selection of environmental performance as a moderating variable because according to $\mathrm{Lu} \&$ Taylor (2018) companies that have good environmental performance will send a signal to the public to get praise and not harm stakeholders. Companies that have good environmental performance will be a driving force to be disclosed to the public that the companies have good environmental policy.

Stakeholder, legitimacy, and agency theories are used as the theoretical basis in this study. Stakeholder theory explains personal interests are not only the purpose of the entity in carrying out its operational activities but also it must be able to share the benefits of its existence for stakeholders (Ghozali \& Chariri, 2007). Therefore, the form of responsibility that companies can carry out in fulfilling stakeholder rights is environmental disclosure.

Legitimacy theory explains the harmony of values held by companies and values found in society (Ghozali \& Chariri, 2007). If both values are found to be contradictory, companies need to evaluate their social values and harmonize the values that exist in society. Environmental disclosure is considered as a medium that will influence people's views towards the company so that it will create good legitimacy.
Agency theory explains principal and other parties, namely agents who have contracts between the two (Jensen \& Meckling, 1976). The misalignment of desires between principal and agent will trigger the formation of conflict. Environmental disclosure is expected to align interests between principal and agent to grow company's image for the welfare of shareholders and the continuity of company's life (Fashikhah et al., 2018).

Earnings management is an action that can reduce the credibility of financial statements. Agency theory explains that agency problems arise when agents maximize their own interests such as learning management (Sun et al., 2010). Earnings management practices bring through information asymmetry between agents and principals about actual economic condition of the company and influence principal's decisions that rely on financial statements. Managers who practice earnings management will look for ways to anticipate suspicions and active actions that threaten their position. Managers will have the motivation to provide additional information in the form of environmental disclosure in an effort to cover earnings management (Julianto \& Sjarief, 2016).

Managers who have control over decision-making will conduct voluntary disclosure in the form of environmental disclosure that will increase the transparency of company information. Therefore, companies that practice earnings management will expand environmental disclosures to divert attention that is expected to increase stakeholder trust. Research conducted by Prior et al.(2008), Machmuddah et al., (2017) and Ningsih (2017) show earnings management relates positively significantly to the disclosure of corporate environment.

\section{$\mathrm{H}_{1}$ : Earnings management has a significant positive effect on environmental disclosure}

Agency conflict is caused by inequality of desire between company manager and company owner. Jensen \& Meckling (1976) stated that one of the solutions that can reduce agency conflicts is managerial ownership. Greater managerial ownership makes managers work more actively to maximize firm value for the welfare of shareholders and for the continuity of the company. Thus, the manager will present relevant information for stakeholders which are wider.

Voluntary information in the form of environmental disclosure is calculated as a policy in improving the company's image. The company's improved image will certainly have a positive impact on the interests of managers as shareholders. Therefore, environmental disclosure can be used as a way for managers to align their interests as managers and shareholders (Fashikhah et al., 2018). This is as the more managerial ownership, management is considered to be more active in conducting activities that are beneficial in improving the company's image. Research conducted by Oktafianti \& Rizki (2015) and Fashikhah et al., (2018) show the positive effect between managerial ownership and environmental disclosure. 
Managerial ownership has a significant positive effect on environmental disclosure.

Firm size indicates small or large size of the company, one of which is measured by the size of corporate total assets. Companies with larger total assets are considered more capable in conveying information related to the wider environment. Moreover, the disclosure of environmental information requires high costs (Diantimala \& Amril, 2018). Legitimacy theory also states that large companies tend to get the attention from the community because the impact caused by their activities is greater than those of small companies. Therefore, large companies will prevent the emergence of negative opinions that threaten the continuity of the company with more environmental disclosure. Diantimala \& Amril (2018), Ashfaq \& Rui (2018), and Ismail et al.(2018) found firm size obtains significant positive result with environmental disclosure.

Firm size has a significant positive effect on environmental performance.

The information asymmetry in agency theory allows opportunistic actions by managers. One of them is earnings management. Managers who practice earnings management will expand information transparency with environmental disclosure to reduce agency conflicts that arise from the inequality of desires between agents and principals (Julianto \& Sjarief, 2016).

Legitimacy theory explains that in order to achieve legitimacy, companies need to work according to the norms and expectations of the community where they stand. A good environmental performance will be a positive signal to the community and prove that their activities do not harm the stakeholders (Lu \& Taylor, 2018). Earnings management will have a negative impact on the company's image. Therefore, environmental performance that can increase public trust can be used by managers in diverting the issue of earnings management practices. Companies that have good environmental performance will encourage the shift of earnings management issue with wider environmental disclosure.

Environmental performance is able to moderate significantly the effect of earnings management on environmental disclosure.

The difference of desires of desires between owners and managers of the company will lead to agency conflict. Agency theory explains that the existence of managerial ownership is expected to reduce agency conflict (Jensen \& Meckling, 1976). Manager as the owner of the company will try to improve the positive image that will add value to the company. One of the policies that can be taken is environmental disclosure which is increasingly widespread.

Environmental performance is expected to increase firm value (Diantimala \& Amril, 2018). A good environmental performance will motivate managers as owners and managers of the company to work optimally in increasing firm value for the sake of the company's sustainability by disclosing information about the environment more broadly. Managers who have worked on environmental performance will not hide it and will inform stakeholders about their environmental activities. The good condition of the company's environmental performance will encourage complete and transparent environmental disclosure to give a position as a company with good activities (Purnama, 2018). Thus, environmental performance is able to encourage managerial ownership in expanding environmental disclosure.

\section{Environmental performance is able to moderate sig- nificantly the effect of managerial ownership on envi- ronmental disclosure.}

Company is not only responsible to its shareholders. Stakeholder theory states that a company does not merely carry out operational activities for personal gain, but needs to share the meaning of its existence for stakeholders (Ghozali \& Chariri, 2007). Large companies are given more attention by external parties because of their increasingly broad business activities. Thus, the companies seek to submit wider reports on the environment aimed at corporate stakeholders.

Burgwal \& Vieira (2014) revealed legitimacy theory shows that environmental disclosure is the result of social and political demands that companies receive regarding environmental performance to meet the expectations of the community regarding the environment. Greater pressure from the community makes large companies try their best not to get negative opinions arising from the community which presence can be a threat to the company. Environmental performance scores that are often published will attract public attention regarding corporate environmental issues (Deswanto \& Siregar, 2018). Therefore, a good environmental performance can encourage large companies to be broader in environmental disclosure.

Environmental performance is able to moderate significantly the effect of firm size on environmental disclosure.

\section{RESEARCH METHODS}

This research was a deductive study using quantitative research that used secondary data. Non-financial companies listed on the Indonesia Stock Exchange in the 2014-2017 period which amounted to 385 companies were used as the study population. It is implemented purposive sampling method, a sample that is aligned with the specified criteria resulted in 16 companies for 4 years of observation and finally 64 units of analysis were obtained. The sample is determined by the criteria listed in Table 1.

The dependent variable of this research was environmental disclosure. The independent variables were earnings management, managerial ownership, and firm size. Meanwhile, the moderation variable taken was environmental performance. Description of the operational definitions of each variable in this study are in Table 2. 
Table 2. Operational Definitions of Research Variables

\begin{tabular}{|c|c|c|}
\hline Variables & Definition & Measurement \\
\hline $\begin{array}{l}\text { Environmental } \\
\text { Disclosure (ED) }\end{array}$ & $\begin{array}{l}\text { The contribution of company in inform- } \\
\text { ing environmental activities carried out } \\
\text { by the company (Fashikhah et al., 2018) }\end{array}$ & $\begin{array}{l}\text { (Number of items revealed by the company) } \\
\text { (number of GRI environmental disclosure items) } \\
\text { (Deswanto \& Siregar, 2018) }\end{array}$ \\
\hline $\begin{array}{l}\text { Earning management } \\
\text { (DA) }\end{array}$ & $\begin{array}{l}\text { Earning management exists when man- } \\
\text { agers distort stakeholders about the } \\
\text { company's economic performance or to } \\
\text { influence contract decisions that rely on } \\
\text { financial statements (Healy \& Wahlen, } \\
\text { 1998) }\end{array}$ & $\begin{array}{l}\text { Discretionary Accrual (DA) by modified jones model } \\
\text { (Sun et al., 2010) }\end{array}$ \\
\hline $\begin{array}{l}\text { Managerial } \\
\text { Ownership (MO) }\end{array}$ & $\begin{array}{l}\text { Executives or directors of companies } \\
\text { that have stock ownership (Chang \& } \\
\text { Zhang, 2015) }\end{array}$ & $\begin{array}{l}\text { (Number of shares owned @by managers) } \\
\text { (total shares) } \\
\text { (Fashikhah et al., 2018) }\end{array}$ \\
\hline Firm size (FS) & $\begin{array}{l}\text { Big or small size of a company seen } \\
\text { from total assets, total sales, average to- } \\
\text { tal sales, and average total assets (Dewi } \\
\text { \& Yasa, 2017) }\end{array}$ & $\begin{array}{l}\text { Size }=\text { Ln (Total Asset) } \\
\text { (Ashfaq \& Rui, 2018) }\end{array}$ \\
\hline $\begin{array}{l}\text { Environmental } \\
\text { Performance (EP) }\end{array}$ & $\begin{array}{l}\text { Environmental certification which is } \\
\text { considered a signal that shows corporate } \\
\text { interest and willingness to improve envi- } \\
\text { ronmental quality (Ismail et al., 2018) }\end{array}$ & $\begin{array}{l}\text { PROPER rating } \\
\text { Gold: } 5 \\
\text { Green: } 4 \\
\text { Blue: } 3 \\
\text { Red: } 2 \\
\text { Black: } 1 \\
\text { (Deswanto \& Siregar, 2018) }\end{array}$ \\
\hline
\end{tabular}

Source: Researcher summary, 2019

Data collection technique in this study used documentation method. Data in the form of secondary data included annual reports, sustainability reports and PROPER assessment reports by the government in 2014-2017. Hypothesis testing used descriptive analysis technique and inferential analysis technique. Before carrying out hypothesis testing, data must pass for the classical assumption test. The moderation variable testing hypothesis was tested using IBM SPSS version 24 with a moderation regression analysis technique that is absolute difference value test using a significance level of $5 \%$. Regression equation through absolute difference value test using the equation formula 1 :

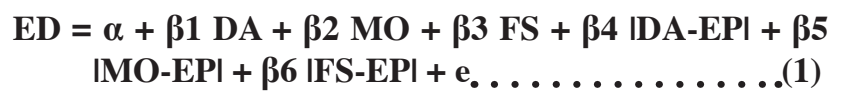

\section{RESULTS AND DISCUSSIOS}

Descriptive statistics were carried out to see the maximum value, minimum standard deviation, and variables of environmental disclosure, earnings management, managerial ownership, firm size, and environ- mental performance. The results of descriptive statistics are Table 3.

The frequency distribution is arranged based on data taken from 64 units of analysis which are then sorted from the highest to the lowest score and classified into 5 groups of interval classes, namely very low, low, medium, high and very high. The frequency distribution shows the highest percentage of ED $29.7 \%$ at very low and low positions. The highest percentage of EM is $34.4 \%$ in the moderate position. The highest percentage of $\mathrm{MO}$ is $93.8 \%$ in the very low position. The highest percentage of FS is $51.6 \%$ in the low position and for the highest percentage of EP variable is $67.2 \%$ in the moderate category.

The normality test, the multicollinearity test, the autocorrelation test, and the heteroscedasticity test are performed on the classical assumption test. The normality test which uses the Kolmogorov-Smirnov OneSample shows a significance of 0.067 higher than the significance level of 0.05 so it can be understood that the residual data is normally distributed. The result of multicollinearity test reveals a VIF number lower than 10

Table 3. Descriptive statistical results

\begin{tabular}{llllll}
\hline & $\mathrm{N}$ & Minimum & Maximum & Mean & Std. Deviation \\
\hline Environmental Disclosure & 64 & 0.1333 & 0.9706 & 0.420987 & 0.1920964 \\
Discretionary Accruals & 64 & -0.1465 & 0.4125 & 0.159584 & 0.1246425 \\
Managerial Ownership & 64 & 0.00000 & 0.72209 & 0.0473491 & 0.16206529 \\
Firm Size & 64 & 22.6040 & 26.4124 & 24.045401 & 0.8426038 \\
Environmental Performance & 64 & 2 & 5 & 3.39 & 0.681 \\
\hline
\end{tabular}

Source: Secondary data processed, 2019 
Table 4. Hypothesis Testing

\begin{tabular}{lcrc}
\hline \multicolumn{1}{c}{ Hypothesis } & $\beta$ & Sig & Results \\
\hline Earnings management has a significant positive effect on environmental disclosure. & 0.030 & 0.255 & Rejected \\
Managerial Ownership has a significant positive effect on environmental disclosure. & -0.103 & 0.062 & Rejected \\
Firm size has a significant positive effect on environmental disclosure. & -0.036 & 0.346 & Rejected \\
Environmental performance significantly moderates the effect of earnings manage- & -0.028 & 0.499 & Rejected
\end{tabular}

ment on environmental disclosure.

Environmental performance significantly moderates the effect of managerial owner- $0.104 \quad 0.040$ Accepted ship on environmental disclosure.

Environmental performance significantly moderates the effect of firm size on environ- $0.016 \quad 0.701$ Rejected mental disclosure.

Source : Secondary data processed, 2019

and the tolerance values of all independent variables are higher than 0.10 , so the conclusion is that the regression model is not affected by multicollinearity symptoms. The autocorrelation test produces a durbin-watson value of 1.831 , which is higher than the $\mathrm{dU}$ value and lower than 4 -dU $(1.7351<1.831<2.2649)$, it can be concluded that there is no autocorrelation in the research data. The heteroscedasticity test through white test concludes that there is no heteroscedasticity with the $c^{2}$ count value (10.88) smaller than $c^{2}$ table (95.649). The classical assumption testing shows that the results of all variables pass the classical assumption test, then hypothesis testing can be proceeded. Hypothesis testing can be written through the equation Formula 2.

$$
\begin{aligned}
\mathrm{ED}= & 0.322+0.030 \mathrm{DA}-0.103 \mathrm{MO}-0.036 \mathrm{FS}-0.028 \mid \mathrm{DA}- \\
& \mathrm{EP}|+0.104| \mathrm{MO}-\mathrm{EP}|+0.016| \mathrm{FS}-\mathrm{EP} \mid \ldots \ldots \text { (2) }
\end{aligned}
$$

The result of the coefficient of determinant test shows the adjusted $\mathrm{R}^{2}$ value of 0.207 which means that $20.7 \%$ of the environmental disclosure variable can be explained by the three independent variables, namely earnings management, managerial ownership, and firm size as well as the relationship between the independent variable and environmental performance as the moderating variable. Conversely, the remaining $79.3 \%$ is explained by other variables outside the model. The results of hypothesis testing can be observed in Table 4 .

\section{The Effect of Earning Management on Environmental Disclosure}

The result shows earnings management has no effect on environmental disclosure. Managers have incentives to engage in income increasing or income decreasing (Sun et al., 2010). In the research data, the most earnings management done by the companies is in the medium category $(34.4 \%)$ at an interval of DA values of $0.077-0.188$. The remaining $65.6 \%$ is spread in other categories, evenly distributed in the low to very low categories which are negative ie DA 0.077 to -0.146 and high to very high categories with positive intervals, namely DA 0.188 to 0.412 . DA in the research data shows that the companies evenly make income increasing and income decreasing.

The best DA value is DA which approaches 0 (zero) which indicates the lower level of earnings management (Khaiyat, 2016). DA which is not absolute is assumed causing earnings management does not affect environmental disclosure because it does not show the extent of DA value to zero point, which indicates the higher level of earnings management. Sun et al.(2010) mentioned the absolute DA value as a basis for measuring earnings management that may be both increasing income and decreasing income. The result of this study is in line with the research Sun et al. (2010), Julianto \& Sjarief (2016) and Sari \& Nimba (2015).

\section{The Effect of Managerial Ownership on Environmen- tal Disclosure}

Managerial ownership is insignificant with environmental disclosure. The absence of managerial ownership effect on environmental disclosure is allegedly because $93.8 \%$ of the frequency distribution of managerial ownership in non-financial companies is in the low category. Low managerial ownership causes high agency conflicts that lead to information asymmetry that will be utilized by managers in maximizing personal goals by increasing the incentive value. Therefore, agents and principals' goals are less aligned in terms of increasing firm value by expanding the company's environmental disclosure. The result of this study is not in line with agency theory that managerial ownership can be used to reduce agent and principal interests. However, on the other hand, in line with the findings of Chang \& Zhang (2015), Donnelly \& Mulcahy (2008) and Ningsih (2017).

\section{The Effect of Firm Size on Environmental Disclosure}

Firm size is insignificant with environmental disclosure. The absence of firm size effect on the environmental disclosure is presumed that the company has not found the effectiveness of environmental disclosure, which means the company has not considered environmental disclosure as a policy that has a positive impact in the future (Anggrarini \& Taufiq, 2017). For this reason, small or large size of companies does not have impact on the extent of corporate environmental disclosure. The company generally has a goal to increase its assets. Meanwhile, the costs incurred for an increasingly broad environmental disclosure is quite large. The nature of environmental disclosure, which is still voluntary, makes the extent of disclosure emerge from the company's concern for the environment and is limited to compliance with applicable regulations. The result of this study rejects legitimacy theory where larger companies will 
have greater pressure for environmental disclosure. The result of this study is in line with the findings of Darus et al. (2014), Ariningtika \& Kiswara (2013) and Anggrarini \& Taufiq (2017).

\section{The Effect of Earning Management on Environmen- tal Disclosure which is moderated by Environmental Performance}

Environmental performance is not able to influence earnings management on environmental performance. Lu \& Taylor (2018) stated that it is apparently that companies respond to government or public pressure on environmental disclosure only at the minimum level required. Even with the existence of regulations, companies with poor environmental performance are reluctant to disclose them. The frequency distribution shows the highest level of environmental performance in the blue category of $67 \%$. Minister of the Environment Regulation No. 6/2013 states that the blue color in PROPER meaning that environmental management efforts are in accordance with the laws and regulations.

Legitimacy theory is the theory that underlies environmental disclosure. Where companies must operate within the norms and expectations of the communities in which they operate. Non-financial companies only have a minimum level of environmental performance which is in accordance with regulations to respond to public and government pressure. This is not used by managers in covering earnings management practices. Therefore, low and high environmental performance has no relation with earning management and environmental disclosure.

The Effect of Managerial Ownership on Environmental Disclosure with Moderated Environmental Performance

The result of this study shows that environmental performance moderates the effect of managerial ownership on environmental disclosure. The result of the study is relevant to agency theory where the existence of manager's stock will unite the interests of agents and principals in increasing the value of the company for the continuity of the company's life and the prosperity of the shareholders. Environmental performance is one of the ways to increase firm value.

Managerial ownership does not affect environmental disclosure. Then, the presence of environmental performance in this study is able to give the positive relationship effect between the two. Companies that get good environmental performance will motivate managers in increasing the value of the company for the continuity of the company and the prosperity of shareholders by disclosing more environmental information. Therefore, environmental performance can encourage the extension of environmental disclosure even though managerial ownership in companies is high or low. It is proven where PTBA in the research data has high environmental performance and extensive environmental disclosure with high managerial ownership. Unlike SMCB which does not have managerial ownership, it has a broad level of environmental disclosure supported by the acquisition of high environmental performance. Based on the research data, $93 \%$ of the companies that have low managerial ownership continue to carry out environmental disclosure supported by the acquisition of environmental performance.

\section{The Effect of Firm Size on Environmental Disclosure moderated by Environmental Performance}

The result of this study shows that environmental performance does not moderate firm size of environmental disclosure. The result of this study contradicts legitimacy theory where large companies get more social and political pressure related to the environmental performance to meet public expectations. This means that low or high level of environmental performance obtained by the companies does not affect the size of the company in expanding environmental disclosure. The average environmental performance in non-financial companies is in the blue category which shows that environmental management is limited to obeying the laws and regulations and forms of responsibility to the community. Meanwhile, high environmental performance is obtained for companies that achieve environmental excellence.

Environmental disclosure requires higher costs (Diantimala \& Amril, 2018). High environmental performance does not encourage the extension of environmental disclosure for companies becuase of less effective environmental disclosure for the survival of the company in the future. This finding is supported by the research data in which one of the sample companies, SMCB, has a firm size of 23.578 and has environmental performance 5 . The company only does environmental disclosure of 0.3824 which is in the low category. Then, the SMGR firm size of 24.365 which is above the average value, has an environmental performance in the green category of 4. However, this does not encourage companies to expand environmental disclosure. SMGR has a level of environmental disclosure in the low category with a value of 0.3234 .

\section{CONCLUSIONS}

This study examines empirical studies of earnings management, managerial ownership, and firm size on environmental disclosure with environmental performance as a moderating factor. The results of the study conclude that earning management, managerial ownership, and firm size have no effect on environmental disclosure. In addition, environmental performance cannot significantly moderate the effect of earnings management and firm size on environmental disclosure but only environmental performance which can significantly moderate the effect of managerial ownership on environmental disclosure.

Good environmental performance show that the companies have had good policies and strategies related to its environment. Managers also tend to reveal good news compared to bad news related to corporate performance which will have an impact on the sustainability of 
the company's business. Where high environmental performance is able to strengthen the effect of managerial ownership on environmental disclosure. Therefore, this study recommends companies to improve environmental performance to encourage the effect of managerial ownership in implementing environmental disclosure.

The limitation of this study is the value of earnings management measurement which uses the value of non-absolute discretionary accruals, in which considers negative DA values as low earnings management and positive DA as higher earnings management. Suggestion for further research is to make value of discretionary accruals in calculating earnings management. This means, both negative and positive DA value is determined by the DA value getting further away from the point 0 . Because both positive and negative DA values indicate that managers make earnings management to cover the actual economic performance of the company.

\section{REFERENCES}

Anggrarini, D., \& Taufiq, E. (2017). Pengaruh Ukuran Dewan Komisaris dan Ukuran Perusahaan Terhadap Environmental Disclosure. Jurnal Ekonomi Manajemen \& Bisnis, 18(2), 119-126.

Ariningtika, P., \& Kiswara, E. (2013). Pengaruh Praktik Tata Kelola Perusahaan yang Baik Terhadap Pengungkapan Lingkungan Perusahaan. Diponegoro Journal of Accounting, 2, 1-11.

Ashfaq, K., \& Rui, Z. (2018). Revisiting the relationship between corporate governance and corporate social and environmental disclosure practices in Pakistan. Social Responsibility Journal. https://doi.org/10.1108/SRJ01-2017-0001

Burgwal, D. Van De, \& Vieira, R. J. O. (2014). Environmental Disclosure Determinants in Dutch Listed Companies. R. Cont Fin. - USP, Sao Paulo, 25(64), 60-78.

Chang, K., \& Zhang, L. (2015). The Effects of Corporate Ownership Structure on Environmental Information Disclosure - Empirical Evidence from Unbalanced Penal Data in Heavy-pollution Industries in China. Wseas Transactions on Systems and Control, 10(1996), 405-414.

Darus, F., Mad, S., \& Yusoff, H. (2014). The Importance of Qwnership Monitoring and Firm Resources on Corporate Social Responsibility ( CSR) of Financial Institutions. Procedia - Social and Behavioral Sciences, 145, 173180. https://doi.org/10.1016/j.sbspro.2014.06.024

Deswanto, R. B., \& Siregar, S. V. (2018). The Associations Between Environmental Disclosures with Financial Performance, Environmental Performance, and Firm Value. Social Responsibility Journal, 14(1), 180-193. https://doi.org/10.1108/SRJ-01-2017-0005

Dewi, I. A. P. O. Y., \& Yasa, G. W. (2017). Pengaruh Ukuran Perusahaan, Profitabilitas, Tipe Industri dan Kinerja Lingkungan Terhadap Environmental Disclosure. $E$ Jurnal Akuntansi Universitas Udayana, 20, 2362-2391.

Diantimala, Y., \& Amril, T. A. (2018). The Effect of Ownership Structure, Financial and Environmental Performances on Environmental Disclosure. Accounting Analysis Journal, 7(1), 70-77. https://doi.org/10.15294/ aaj.v5i3.20019

Donnelly, R., \& Mulcahy, M. (2008). Board Structure , Ownership, and Voluntary Disclosure in Ireland. Corporate Governance, 16(5), 416-429. https://doi.org/10.1111/ j.1467-8683.2008.00692.x

Fashikhah, I., Rahmawati, E., \& Sofyani, H. (2018). Determinan Environmental Disclosure Perusahaan Manufatur di Indonesia dan Malaysia. Jurnal Akuntansi Indonesia, 7(1), 31-55.

Ghozali, I., \& Chariri, A. (2007). Teori Akuntansi. Semarang: Badan Penerbit Universitas Diponegoro.

Healy, P. M., \& Wahlen, J. M. (1998). A Review of The Earnings Management Literature and Its Implications for Standard Setting. Accounting Horizon, 12(4).

Ismail, A. H., Rahman, A. A., \& Hezabr, A. A. (2018). Determinants of Corporate Environmental Disclosure Quality of Oil and Gas Industry in Developing Countries. International Journal of Ethics and Systems. https://doi. org/10.1108/IJOES-03-2018-0042

Jensen, M. C., \& Meckling, W. H. (1976). Theory of the Firm : Managerial Behavior, Agency Costs and Ownership Structure. Journal of Financial Economics, 3(4), 305-330.

Julianto, M., \& Sjarief, J. (2016). Analisis Pengaruh Kinerja Lingkungan, Manajemen Laba, Ukuran Perusahaan, dan Profitabilitas Terhadap Pengungkapan Lingkungan Pada Perusahaan Manufaktur Yang Terdaftar di Bursa Efek Indonesia. Jurnal Akuntansi, 2, 147-171.

Khaiyat. (2016). Indikasi Manajemen Laba Melalui Akrual Discresioner Pada Perusahaan Telekomunikasi di BEI. Jurnal Akuntansi, 1(2).

Khan, A., Muttakin, M. B., \& Siddiqui, J. (2013). Corporate Governance and Corporate Social Responsibility Disclosures : Evidence from an Emerging Economy. J Bus Ethics, 114, 207-223. https://doi.org/10.1007/s10551012-1336-0

Lu, L. W., \& Taylor, M. E. (2018). A Study of The Relationships Among Environmental Performance, Environmental Disclosure, and Financial Performance. Asian Review of Accounting, 26(1), 107-130. https://doi. org/10.1108/ARA-01-2016-0010

Machmuddah, Z., Syafruddin, M., Muid, D., \& Utomo, S. D. (2017). Manajemen Laba, Pengungkapan Lingkungan Perusahaan dan Mekanisme Tata Kelola Perusahaan. Jurnal Dinamika Akuntansi Dan Bisnis, 4(1), 57-72.

Ningsih, R. F. (2017). Pengaruh Mekanisme Good Corporate Governance dan Manajemen Laba Terhadap Environmental Disclosure. Padang : Universitas Negeri Padang.

Oktafianti, D., \& Rizki, A. (2015). Pengaruh Kepemilikan Manajerial, Ukuran Perusahaan dan Kinerja Keuangan Terhadap Corporate Environmental Disclosure Sebagai Bentuk Tanggung Jawab Sosial dalam Laporan Tahunan ( Studi pada Perusahaan Peserta Proper 2011-2013 ). Simposium Nasional Akuntansi XVlll, (Lampung), 22.

Prior, D., Surroca, J., \& Tribó, J. A. (2008). Are Socially Responsible Managers Really Ethical? Exploring the Relationship Between Earnings Management and Corporate Social Responsibility. Corporate Governance, 16(3), 160-177. https://doi.org/10.1111/j.14678683.2008.00678.x

Purnama, D. (2018). Analisis Karakteristik Perusahaan dan Environmental Performance terhadap Environmental Disclosure. Jurnal Riset Keuangan Dan Akuntansi, 4(1), $1-14$.

Sari, I. G. A., \& Nimba, N. L. (2015). Pengaruh Manajemen Laba, Kinerja Keungan, Ukuran Perusahaan dan Pertumbuhan Perusahaan Pada Pengungkapan Corporate Social Responsibility. E-Jurnal Akuntansi Universitas Udayana, 11.3, 629-645.

Sun, N., Salama, A., Hussainey, K., \& Habbash, M. (2010). Corporate environmental disclosure, corporate governance and earnings management, 25(7), 679-700. https://doi.org/10.1108/02686901011061351

Wahana Lingkungan Hidup. (2018). Tinjauan Lingkungan Hidup 2018. Wahana Lingkungan Hidup. Diakses dari http://walhi.or.id/ 